Discussion Paper No. 09-047

\title{
What Determines Local Governments' Technical Efficiency? The Case of Road Maintenance
}

Alexander Kalb

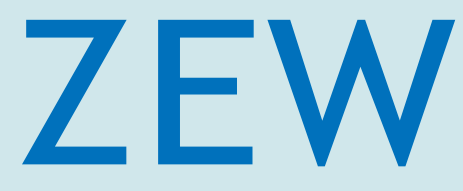

Zentrum für Europäische Wirtschaftsforschung $\mathrm{GmbH}$

Centre for European Economic Research 


\title{
Discussion Paper No. 09-047 \\ What Determines Local Governments' Technical Efficiency? The Case of Road Maintenance
}

\author{
Alexander Kalb \\ Download this ZEW Discussion Paper from our ftp server: \\ ftp://ftp.zew.de/pub/zew-docs/dp/dp09047.pdf
}

Die Discussion Papers dienen einer möglichst schnellen Verbreitung von neueren Forschungsarbeiten des ZEW. Die Beiträge liegen in alleiniger Verantwortung der Autoren und stellen nicht notwendigerweise die Meinung des ZEW dar.

Discussion Papers are intended to make results of ZEW research promptly available to other economists in order to encourage discussion and suggestions for revisions. The authors are solely responsible for the contents which do not necessarily represent the opinion of the ZEW. 


\section{Non-Technical Summary}

While there are numerous studies on the measurement of the technical or cost efficiency of local governments, the analysis of the main drivers of this efficiency has attracted far less attention in this literature. However, information about the main sources of (in)efficiency are not unimportant, since they can provide useful information for (local) policy-makers. Therefore, the aim of this paper is to add to the existing literature by studying the determinants of local governments' efficiency. For this purpose we focus on one particular area of public goods provision, namely the construction and maintenance of (county) roads, instead of the local government as a whole. This avoids, at least to a certain degree, the problem of defining a comprehensive set of reasonable input and output indicators fully describing local governments' activities, and therefore reduces potential sources of measurement errors.

Our empirical analysis is based on a broad panel of German counties rather than a crosssection used in the most previous studies which investigated the determinants of efficiency. The German counties are an interesting case to study, since one of the main tasks of these counties is the construction and maintenance of county roads. In order to determine the main drivers of efficiency in road maintenance, we first calculate efficiency indices using non-parametric (Data Envelopment Analysis) and parametric (stochastic frontier analysis) estimation techniques. In a second step, we examine how these efficiency indices can be explained by a number of exogenous (e.g. socio-economic, fiscal, political) variables. More specifically, we apply and compare four different estimation approaches to detect the potential sources of (in)efficiency. This broad variety of estimation approaches allows us to test and check the robustness of the derived results.

The results of our analysis show that (controlling for numerous characteristics of the counties) the disposable income of the counties' citizens, intergovernmental grants for county roads, and the payments to the counties influence technical efficiency negatively. For the political variables we find weak evidence that efficiency decreases with an increasing share of seats of left-wing parties in the county council; on the other hand, the hypothesis that efficiency decreases with the degree of political concentration in the county council could not be confirmed. Moreover, the analysis shows that not all of the four estimation approaches are consistent - concerning the sign of the coefficients as well as the (statistical) significance. Therefore, focusing on just one estimation method, as it was done in the most previous studies investigating the determinants of local governments' efficiency, may be deceptive. To test the robustness of the results, different estimation approaches should be applied and compared. 


\section{Zusammenfassung}

In den vergangenen Jahrzehnten hat sich ein Literaturstrang herausgebildet, der sich mit der Messung der technischen Effizienz des öffentlichen Sektors beschäftigt. Hierbei wurde sowohl die Effizienz von Teilbereichen des öffentlichen Sektors, wie beispielsweise Schulen oder Krankenhäuser, als auch die Gesamteffizienz von (lokalen) Gebietskörperschaften, wie beispielsweise Kommunen, untersucht. Einen eher geringeren Stellenwert in diesem Literaturstrang hat bisher jedoch das Verständnis für die Bestimmungsfaktoren dieser technischen Effizienz erfahren. Informationen über die Hauptquellen von potenziellen Ineffizienzen im öffentlichen Sektor können aber sehr nützlich sein, da sie hilfreiche Anhaltspunkte für Politiker oder Amtsinhaber liefern, wie potenzielle Ineffizienzen eingedämmt werden könnten. Aus diesem Grund stellt dieser Beitrag den Versuch dar, diese Lücke zu schließen. Um potenzielle Messfehler bei der Bestimmung von Input- und Outputindikatoren zu minimieren, werden dabei nicht die Gebietskörperschaften als Ganzes herangezogen, sondern nur ein ausgewählter wichtiger Teilbereich des öffentlichen Sektors, nämlich die Bereitstellung und Instandhaltung von Straßen.

Im Gegensatz zu zahlreichen Vorgängerstudien, welche die Determinanten der technischen Effizienz des öffentlichen Sektors in einer Querschnittsanalyse untersucht haben, basiert die empirische Analyse der vorliegenden Studie auf einem umfangreichen Panel von deutschen (baden-württembergischen) Stadt- und Landkreisen. Diese eignen sich hierfür besonders gut, da eine der Hauptaufgaben der Stadt- und Landkreise die Bereitstellung und Instandhaltung von Kreisstraßen darstellt. Um nun die Hauptbestimmungsfaktoren der Effizienz im kommunalen Straßenbau zu analysieren, werden in einem ersten Schritt - mithilfe von nichtparametrischen (Data Envelopment Analysis) und parametrischen (stochastic frontier analysis) Schätzverfahren - zunächst Effizienzindikatoren berechnet. Nach der Ermittlung der Effizienzindikatoren wird anschließend in einem weiteren Schritt untersucht, welche Faktoren (z.B. sozioökonomische, fiskalische oder politische Variablen) die Effizienz beeinflussen. Hierfür werden vier unterschiedliche Schätzverfahren (Regressionsanalysen) herangezogen. Die Anwendung unterschiedlicher Regressionstechniken ermöglicht es, die hergeleiteten Ergebnisse zu vergleichen und einem Robustheitstest zu unterziehen.

Die Ergebnisse der empirischen Analyse zeigen, dass - bei gleichzeitiger Kontrolle für die unterschiedlichen Charakteristika der Stadt- und Landkreise - die Effizienz mit dem verfügbaren Einkommen der Bürger eines Kreises, der Kreisumlage bzw. den Gewerbesteuereinnahmen sowie den Finanzzuweisungen für die Kreisstraßen sinkt. Was den Einfluss von politischen Variablen auf die Effizienz angeht, kann die Hypothese nicht bestätigt werden, dass die Ef- 
fizienz mit zunehmendem politischem Wettbewerb (im Kreistag) steigt. Auf der anderen Seite deuten die Ergebnisse darauf hin, dass Kreise mit einem höheren Sitzanteil von linken Parteien im Kreistag ein geringeres Effizienzniveau aufweisen. Darüber hinaus zeigt die Analyse, dass die Ergebnisse der vier unterschiedlichen Regressionsverfahren im Hinblick auf die Vorzeichen der Koeffizienten sowie auf die (statistische) Signifikanz nicht immer korrespondieren. Die Fokussierung auf nur ein Schätzverfahren, wie es in der vergangenen Literatur häufig der Fall war, kann daher zu fehlerhaften Interpretationen führen; bei Effizienzanalysen sollten zur Überprüfung der Robustheit der Ergebnisse immer Verfahren verglichen werden, die auf unterschiedlichen Schätzansätzen basieren. 


\title{
What Determines Local Governments' Technical Efficiency? The Case of Road Maintenance
}

\author{
Alexander Kalb* (ZEW)
}

September 2009

\begin{abstract}
:
In this paper we investigate the determinants of local governments' technical efficiency in road maintenance for a panel of German counties using a broad variety of estimation approaches. More specifically, we calculate efficiency indices using non-parametric (DEA) and parametric (stochastic frontier analysis) reference technologies, and examine how these efficiency indices can be explained by estimating and comparing four different regression models. The results of our analysis show that (controlling for numerous characteristics of the counties) the disposable income of the counties' citizens, intergovernmental grants (for county roads), and the payments to the counties influence efficiency negatively. Concerning political variables we find weak evidence that efficiency decreases with an increasing share of seats of left-wing parties in the county council; the hypothesis that efficiency decreases with the degree of political concentration in the county council could not be confirmed.
\end{abstract}

Key Words: Technical Efficiency; Road Maintenance; Stochastic Frontier Analysis; Data Envelopment Analysis; German counties

JEL Classification: H11, R30, R51

Acknowledgements: I would like to thank Uwe Brixy, Lars P. Feld, Paul Frijters, Friedrich Heinemann, Benno Torgler, and participants of the International Summer Conference in Regional Science 2009 in Luebeck for helpful comments and suggestions. Support by the German Research Foundation (DFG) within its Priority Programme 1142 "Institutionelle Gestaltung föderaler Systeme" is gratefully acknowledged.

\footnotetext{
*Centre for European Economic Research (ZEW) ～Phone: $\quad+496211235282$

$\mathrm{L} 7,1$

Fax: $\quad+496211235223$

D-68161 Mannheim, Germany

E-mail: $\quad$ kalb@zew.de
} 


\section{Introduction}

The measurement of the performance or efficiency of the public sector has received increasing attention in recent years. One reason for this is that the provision of public goods and services by (local) governments requires funding. Often these funds derive - directly or indirectly - from taxation. Since the citizens of (local) jurisdictions have to pay these taxes, they are interested in an efficient provision of the public goods and services, that is, they want the (local) government to provide as many public goods as possible for a given amount of (fiscal) costs. While there are numerous studies on the measurement of (local) governments' (technical) efficiency (for a review see e.g. De Borger and Kerstens, 2000 and Worthington and Dollery, 2000), the analysis of the main drivers of this efficiency has attracted far less attention in this literature. ${ }^{1}$ Information about the main sources of efficiency, however, are not unimportant, since they can "provide useful information to policy-makers" (De Borger and Kerstens, 1996a, p. 147). Therefore, the aim of this paper is to add to the existing literature by studying the determinants of efficiency for a broad panel of German counties. For this purpose we focus on one particular area of local public good provision, namely road maintenance, instead of the local government as a whole. This avoids, at least to a certain degree, the problem of defining a comprehensive set of reasonable input and output indicators fully describing local governments' activities.

Despite the numerous studies measuring either the technical efficiency of (local) governments as a whole (global approaches) or particular areas of (local) public goods provision (like waste collection, police services or hospitals), only few studies have tried to assess the efficiency of local road maintenance so far. In fact, there are only a couple of studies investigating the scale and technical efficiency of local road maintenance for several US states: Deller et al. (1988) and Chicoine et al. (1989) examine the size efficiency in the production of rural roads by means of cost functions. Both studies identify substantial size inefficiencies and conclude that cost reductions could be realised by restructuring the production of rural roads. Deller and Nelson (1991), Deller et al. (1992), Deller (1992) and Deller and Halstead (1994), on the other hand, investigate the technical efficiency of rural road maintenance using different parametric and non-parametric estimation techniques. Their estimation results suggest that road maintenance costs are 14 to 50 percent higher than necessary due to production inefficiencies. Apart from these studies, Rouse et al. (1997) examine the performance (efficiency, effectiveness and economy) of highway maintenance activities for a sample of territorial local authorities (TLAs) in New Zealand. Using Data Envelopment Analysis, the authors estimate an average efficiency score of $89 \%$, meaning that the local authorities

${ }^{1}$ An overview of the literature on the determinants of (local) governments' efficiency will be provided in section 3 . 
in New Zealand (on average) should be able to attain the same level of output (i.e. road maintenance) by using only $89 \%$ of total expenditures they are currently using. Finally, Hjalmarsson and Odeck (1996) analyse the efficiency of trucks in road construction and maintenance operated by the Norwegian Public Roads Administration (PRA). The authors also find evidence for substantial inefficiencies among the PRAs. Moreover, their results suggest that neither the age nor the brand of the trucks influence efficiency.

The present study adds to this previous literature in three main ways. Firstly, to the best of our knowledge, we are the first who examine the determinants of efficiency for the case of (local) road maintenance. As mentioned above, the usage of such a specific approach (rather than a global approach) reduces the problem of finding appropriate input and output indicators and therefore potential sources of measurement errors. Secondly, we analyse the determinants of efficiency by applying and comparing different cost frontier models (stochastic frontier approaches and DEA) rather than using only one estimation approach (as done by the most previous studies). Specifically, the estimation methods which are used to explain the variation in efficiency correct for the bias arising in typical two-step approaches by employing a one-step approach in the stochastic frontier analysis (proposed by Battese and Coelli, 1995) and a (double) bootstrapping correction in the DEA-analysis (proposed by Simar and Wilson, 2007). Thirdly, our empirical analysis is based on a broad panel of German counties (rather than a cross-section used in the most previous studies which investigated the determinants of efficiency). The German counties are an interesting case to study, since one of the main tasks of these counties is the construction and maintenance of county roads. The main results of our analysis show that (controlling for numerous characteristics of the counties) the disposable income of the counties' citizens, intergovernmental grants (for county roads), and the payments to the counties influence technical efficiency negatively. For the political variables we find weak evidence that efficiency decreases with an increasing share of seats of left-wing parties in the county council; on the other hand, the hypothesis that efficiency decreases with the degree of political concentration in the county council could not be confirmed. Moreover, the analysis shows, that it is important to test the robustness of the results by applying and comparing different (frontier) estimation techniques.

The paper is organised as follows. Section 2 introduces the methodological approaches used in this paper. In section 3 we briefly review the empirical literature on the determinants of local governments' (technical) efficiency. Section 4 describes the empirical analysis including an introduction to the institutional setting of the local governments as well as the main features of local road maintenance in Germany. Finally, conclusions are drawn in section 5. 


\section{Methodology}

For the measurement of the (relative) efficiency of decision making units (here: counties) it is first necessary to define an appropriate set of input and output combinations. The inputs and outputs are then used to construct a best practice frontier - that is a frontier which includes the most efficient decision making units. Subsequently, the (relative) efficiency of the other decision making units lying below the best practice frontier can be determined by measuring the deviation from this frontier. Basically, frontiers have been estimated using two different methods: non-parametric and parametric approaches. ${ }^{2}$ In the present analysis we use one non-parametric approach (DEA) and one parametric approach (stochastic frontier analysis), respectively, to obtain efficiency indices. Both of them will be shortly reviewed in the following. In a second step, these efficiency indices are then used to determine the main drivers of (in)efficiency.

\subsection{Non-Parametric Approach: DEA}

Data Envelopment Analysis (DEA; Farrell, 1957; Charnes et al., 1978) is based on the idea that the best practice frontier envelopes the data as tightly as possible. This envelopment is achieved by solving a sequence of linear programmes, one for each decision making unit. There are several variants of DEA concerning the behavioural objective of the decisionmaking units (input- or output-orientation) and the returns to scale. This study is based on the input-oriented and variable returns to scale variant (see Banker et al., 1984). The inputorientation is applied since the public sector usually has to provide a given amount of output (e.g. in our case roads) and, based on this output, an optimal amount of input(s) will be chosen (and not vice versa); on the other hand, the assumption of constant returns to scale is only appropriate when all decision-making units operate at an optimal scale. Given the fact that we use counties differing considerably in $\operatorname{size}^{3}$ the assumption of variable returns to scale seems to be more appropriate. The DEA model is then specified by solving the

\footnotetext{
${ }^{2}$ For an introduction, see e.g. Fried et al. (2008)

${ }^{3}$ For the descriptive statistics of the data, see subsection 4.2 .
} 
following linear programming problem:

$$
\begin{array}{ll}
\min & \theta_{0} \\
\text { s.t. } & \theta_{0} x_{k, 0}-\sum_{i=1}^{n} \lambda_{i} x_{k, i} \geq 0 \quad \text { with } k=1, \ldots, m \\
& \sum_{i=1}^{n} \lambda_{i} y_{r, i} \geq y_{r, 0} \quad \text { with } r=1, \ldots, s \\
& \sum_{i=1}^{n} \lambda_{i}=0 \\
& \theta_{0}>0,
\end{array}
$$

where $x_{0}$ and $x_{i}$ denote the input levels used by decision-making units 0 and $i$, respectively, to produce the output levels $y_{0}$ and $y_{i}$. Furthermore, $k(r)$ equals the number of inputs (outputs) employed in the production process, $n$ represents the number of decision-making units and the $\lambda_{i}$ 's are weights given to those decisions-making units which are referred to by the comparison with decision-making unit 0. Solving the linear programming problem (1) $n$ times generates the efficiency indices $\theta_{1}$ to $\theta_{n}$, one for each decision-making unit. Providers with efficiency scores of $\theta<1$ are technical inefficient, since they are capable of reducing their input(s) without affecting the amount of output; on the other hand, efficient providers receive efficiency scores of $\theta=1$.

A graphical representation of the input-oriented DEA with variable returns to scale (VRS) is given in figure 1 for the special case of one input $(x)$ and one output( $y)$. As can be seen from the figure, the decision-making units $\mathrm{A}, \mathrm{B}$, and $\mathrm{C}$ form the best practice frontier. The decision-making unit $\mathrm{P}$, however, is deemed to be inefficient since it lies beneath the frontier. The input-oriented technical inefficiency measure of point $\mathrm{P}$ is given by the ratio of the distances $P^{\prime \prime} P^{\prime}$ and $P^{\prime \prime} P$ :

$$
\theta_{P}=\frac{P^{\prime \prime} P^{\prime}}{P^{\prime \prime} P}, \quad 0<\theta_{P}<1 .
$$

The figure also reveals that the reference points for the determination of the inefficiency of decision-making unit $\mathrm{P}$ are given by $\mathrm{A}$ and $\mathrm{B}$.

\subsection{Incorporating Exogenous Influences on Efficiency in DEA-Analyses}

One crucial problem with the efficiency estimates derived from equation (1) is that they treat all decision-making units (here: counties) on the same footing. However, in some cases it may be advisable to take into account exogenous or non-discretionary variables which may influence the performance of the decision-making units. As pointed out by Kalb (2008), we can distinguish two types of such external influences: firstly, characteristics of decision- 
Figure 1: VRS input-oriented DEA example with one input $(x)$ and one output $(y)$

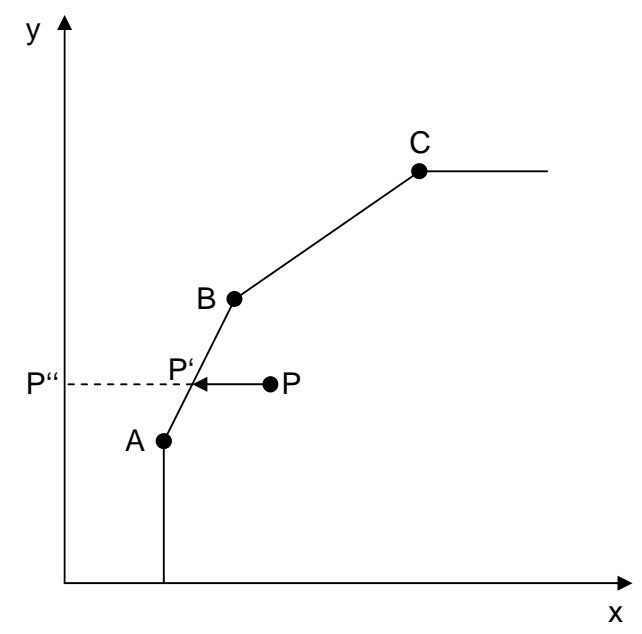

making units which influence their individual production possibilities and which describe the production environment. In our case one example of such an external constraint would be the geographical location of the county: A county in a hilly region may need to spend more money on a given road infrastructure than a county located on the plain. The second type of external influences are the determinants of technical efficiency (which are of main interest in this study), like the political orientation of the local government. These variables affect the level of the counties' technical efficiency but have no impact on the shape of the best practice frontier.

The most common approach to incorporate these exogenous variables into (non-parametric) efficiency analyses is the two-stage method: In a first-stage analysis the linear programming problem (1) is solved, and afterwards, in a second stage, the efficiency scores derived from the first stage are regressed on the exogenous variables. Since the efficiency scores are bounded between zero and one, most researchers used censored regression techniques (Tobit) to estimate the influence of exogenous variables on technical efficiency. ${ }^{4}$ The two-stage approach, however, has been criticised in three ways (see Simar and Wilson, 2007): Firstly, the DEA efficiency indices obtained by solving the linear programming problem (1) are serially correlated (in finite samples), since perturbations of observations that are lying on the best practice frontier will in many cases cause changes in the efficiency scores of other (inefficient) observations. This, however, means that the error term of the second-stage regression is serially correlated as well. Secondly, since the exogenous or non-discretionary variables are correlated with the inputs and outputs (otherwise there would be no need for a second-stage

${ }^{4}$ For a review of two-stage approaches, see Simar and Wilson (2007). 
regression), the non-discretionary variables must also be correlated with the error term of the second-stage regression. Indeed, both correlations disappear asymptotically, but only at a slow rate. Finally, Simar and Wilson (2007) show that the efficiency indices obtained by solving the linear programming problem (1) are biased towards one in small samples.

Simar and Wilson (2007) propose an alternative procedure which avoids the above mentioned problems. This estimation approach is based on a double bootstrap procedure, where, in a first step, the biased efficiency indices are corrected (steps [1] to [4], see below) and, subsequently, the standard errors of the estimated coefficients of the second-stage regression (of the adjusted efficiency indices on the exogenous variables) are corrected (steps [5] to [7], see below). ${ }^{5}$ Moreover, the authors argue that the second-stage regression should be conducted by a truncated instead of a censored (Tobit) regression, since the efficiency indices are truncated (at one) by construction and not because of censoring. Then, the double bootstrap procedure involves the following steps:

[1] Compute the efficiency scores $\hat{\theta}_{i}, i=1, . ., n$ by solving the linear programming problem (1).

[2] Estimate the following truncated regression by maximum likelihood: $\hat{\theta}_{i}=z_{i} \beta+\varepsilon_{i}$, $i=1, \ldots, n$, where $z_{i}$ is a vector of exogenous variables and $\beta$ is a vector of parameters to be estimated - using the $m<n$ observations where $\hat{\theta}_{i}<1$ - and obtain an estimate $\hat{\beta}$ of $\beta$ and $\hat{\sigma}_{\varepsilon}$ of $\sigma_{\varepsilon}$.

[3] Compute $L_{1}$ bootstrap estimates for each $\theta_{i}$ as follows: For each $i=1, \ldots, m$, draw $\varepsilon_{i}$ from the $N\left(0, \hat{\sigma}_{\varepsilon}^{2}\right)$-distribution with left-truncation at $\left(1-z_{i} \hat{\beta}\right)$ and compute $\theta_{i}^{*}=z_{i} \hat{\beta}+\varepsilon_{i}$; set $x_{i}^{*}=x_{i} \frac{\hat{\theta}_{i}}{\theta_{i}^{*}}, y_{i}^{*}=y_{i}$ and compute $\hat{\theta}_{i}^{*}$ by solving the linear programming problem (1), whereas $x_{i}$ in the first constraint is replaced by $x_{i}^{*}$.

[4] For each $i=1, \ldots, n$, compute the bias-corrected efficiency estimator $\tilde{\theta}_{i}=2 \cdot \hat{\theta}_{i}-\bar{\theta}_{i}^{*}$, where $\bar{\theta}_{i}^{*}=\frac{1}{L_{1}} \sum_{l=1}^{L_{1}} \hat{\theta}_{l, i}^{*}$.

[5] Estimate the following truncated regression by maximum likelihood: $\tilde{\theta}_{i}=z_{i} \beta+\varepsilon_{i}$, $i=1, \ldots, n$, where $z_{i}$ is a vector of exogenous variables and $\beta$ is a vector of parameters to be estimated - using the $m<n$ observations where $\tilde{\theta}_{i}<1$ - and obtain an estimate $\tilde{\beta}$ of $\beta$ and $\tilde{\sigma}_{\varepsilon}$ of $\sigma_{\varepsilon}$.

[6] Compute $L$ bootstrap estimates of $\beta$ and $\sigma_{\varepsilon}$ as follows: For each $i=1, \ldots, m$, draw $\varepsilon_{i}$ from the $N\left(0, \hat{\sigma}_{\varepsilon}^{2}\right)$-distribution with left-truncation at $\left(1-z_{i} \tilde{\beta}\right)$ and compute $\tilde{\theta}_{i}^{*}=z_{i} \tilde{\beta}+\varepsilon_{i}$ (again for each $i=1, \ldots, m$ ). Use the maximum likelihood method to estimate the truncated regression of $\tilde{\theta}_{i}^{*}$ on $z_{i}$, yielding bootstrap estimates $\left(\tilde{\beta}^{*}, \tilde{\sigma}_{\varepsilon}^{*}\right)$.

[7] Use the bootstrap values to construct confidence intervals for $\beta$ and $\sigma_{\varepsilon}$ (for a detailed description see Simar and Wilson, 2007, p. 43).

\footnotetext{
${ }^{5}$ Note that Simar and Wilson (2007) also propose a single bootstrap procedure (algorithm 1) where they correct only for the biased standard errors of the estimated coefficients in the second-stage regression. According to Simar and Wilson, however, the double bootstrap procedure (algorithm 2) outperforms the single bootstrap procedure (in terms of coverage of estimated confidence intervals). Therefore, we only present the results of the double bootstrap procedure in section 4 . The results of the single bootstrap procedure are, however, (qualitatively) very similar and are available upon request.
} 
In the present analysis we apply and compare both methods, the second-stage Tobit regression and the double bootstrap procedure proposed by Simar and Wilson (2007). To be in line with the authors we set $L_{1}$ - the number of bootstrap replications in the first procedure - equal to 200 and $L$ - the number of bootstrap replications in the second procedure - equal to 2000 .

\subsection{Parametric Approach: Stochastic Frontier Analysis}

In contrast to the non-parametric estimation techniques, parametric approaches determine the best practice frontier on the basis of a specific functional form using econometric techniques. More specifically, stochastic frontier models (Aigner et al., 1977; Meeusen and Van den Broeck, 1977) decompose the deviation from the efficiency line into two components: an inefficiency part and a part arising from other stochastic influences or measurement errors. Therefore, stochastic frontier models are - compared to non-parametric methods - more precise concerning the definition of the deviation from the best practice frontier. This, however, comes at the cost of having to specify a functional form and making assumptions about the distribution of the inefficiency term. When the true functional form of the input(s) and output(s) is unknown, this problem can be mitigated by choosing a more flexible functional form, namely a translogarithmic function (Christensen et al., 1973) which is an extension of the more basic Cobb-Douglas function. Employing a translogarithmic function, a stochastic frontier model can be written as:

$$
\ln x_{i}=\beta_{0}+\sum_{r=1}^{s} \beta_{r} \ln y_{r, i}+\frac{1}{2} \sum_{r=1}^{s} \sum_{q=1}^{s} \beta_{r, q} \ln y_{r, i} \ln y_{q, i}+\underbrace{v_{i}+u_{i}}_{=\varepsilon_{i}}, \quad i=1, \ldots, n,
$$

where $i$ is again the subscript for the decision-making units and $s$ denotes the number of outputs. As in the non-parametric case, the $y$ 's are the various output variables and $x$ denotes the input variable. Note that in the case of stochastic frontier models the usage of only one input (or output) is possible. Furthermore, the composed error term of equation (3) consists of a symmetric component, $v$, which is usually assumed to be independently and identically normally distributed $N\left(0, \sigma_{v}^{2}\right)$, and a one-sided non-negative component $u \geq 0$, representing inefficiency. The inefficiency component is often assumed to follow a half-normal or a truncated normal distribution. ${ }^{6}$ Both error components are assumed to be independent.

A graphical representation of the stochastic frontier model is given in figure 2 (again for the special case of one input, $x$, and one output, $y$ ). Since the regression model is parametric, the best practice frontier is - in contrast to DEA - a smooth curve. Moreover, the deviation of the decision-making unit $\mathrm{P}$ from the best practice frontier $\left(P P^{\prime}\right)$ is now decomposed in

\footnotetext{
${ }^{6}$ For more details, see Kumbhakar and Lovell (2000).
} 
Figure 2: Example of a stochastic frontier with one input $(x)$ and one output $(y)$

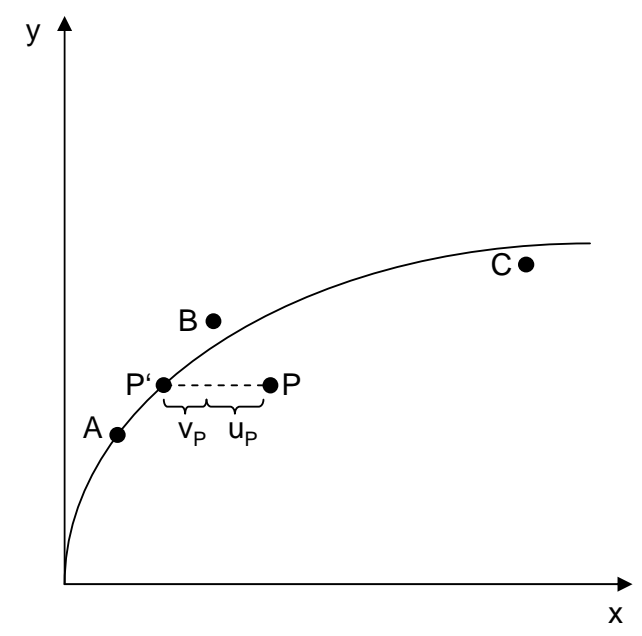

the inefficiency component $u_{P}$ and the (symmetric) component $v_{P}$ capturing the effects of other sources of random noise. In the DEA model, the whole distance $P P^{\prime}$ (see figure 1) was interpreted as inefficiency. Unlike DEA, it is also possible that for some decision-making units the influence of random noise dominates the influence of inefficiency. In this case the decision-making unit ends up above and not beneath the best practice frontier (e.g. point B).

\subsection{Incorporating Exogenous Influences on Efficiency in Stochastic Frontier Analyses}

As with the DEA approach, exogenous or non-discretionary variables have been incorporated into stochastic frontier analyses by using two-stage methods, that is, in a first stage, equation (3) is estimated and afterwards, the efficiency scores $u_{i}, i=1, \ldots n$ obtained from this estimation are regressed on the exogenous variables in an OLS regression (see e.g. Pitt and Lee, 1981; Vitaliano, 1997). However, as pointed out by Kumbhakar and Lovell (2000), there are serious econometric problems with this two-stage approach. Firstly, it must be assumed that the exogenous variables are uncorrelated with the elements of the output vector, $y_{i}$. If this is not the case, the maximum likelihood estimates of the parameters of the model are biased. If the set of inputs, outputs and exogenous variables is very large, this assumption is very likely to be violated. Moreover, since it is assumed in the first stage that the efficiency scores are independently and identically distributed, the assumption that the efficiency scores have a functional relationship with the exogenous variables in the second stage regression is falsified. 
To avoid the second of the above mentioned problems, researchers developed one-step procedures, in which the parameters of the stochastic frontier as well as the parameters of the exogenous variables are estimated simultaneously by Maximum Likelihood (see e.g. Kumbhakar et al., 1991). A one-step procedure that also accounts for the use of panel data was proposed by Battese and Coelli (1995). Since our data are based on a panel of German counties, we make use of this estimator. Using (again) a translogarithmic specification, this leads to the following extension of equation (3):

$$
\begin{gathered}
\ln x_{i, t}=\beta_{0}+\sum_{r=1}^{s} \beta_{r} \ln y_{r, i, t}+\frac{1}{2} \sum_{r=1}^{s} \sum_{q=1}^{s} \beta_{r, q} \ln y_{r, i, t} \ln y_{q, i, t}+\psi_{t}+\underbrace{v_{i, t}+u_{i, t}}_{=\varepsilon_{i, t}} \\
u_{i, t}=\delta_{0}+\sum_{j=1}^{q} \delta_{j} z_{j, i, t}+\psi_{t}+w_{i, t} .
\end{gathered}
$$

where $t$ is the time subscript and $q$ denotes the number of exogenous variables $z$. The random variable $w$ is defined by the the truncation of the normal distribution with zero mean and variance $\sigma_{w}^{2}$ (see Battese and Coelli, 1995). Finally, the time trends $\psi_{t}$ are included to control for both technical change (in the stochastic frontier) and time-varying inefficiency effects.

In the present study we use both methods, the one- and two-step procedure. Together with the two approaches derived in subsection 2.2 we end up with four different estimation approaches. This broad variety of estimation approaches allows us to test the robustness of the derived results. However, before presenting the estimation results, a short review of the literature on the determinants of the technical or cost efficiency of local governments will be provided.

\section{Literature Review}

In the following we give a short review of the literature on the determinants of public sector efficiency. More specifically, we focus on studies which investigate the determinants of the technical or cost efficiency of local governments as a whole (global approaches) instead of studies which focus on (the determinants of efficiency of) specific areas of the public sector like schools, hospitals, utility services and so on. ${ }^{7}$ By doing so, we are able to compare the results of the global approaches with the results of one specific area of public goods provision, namely the construction and maintenance of (county) roads. However, as already mentioned in the introduction, there are only few studies that try to explain variations in local governments' technical or cost efficiency. In fact, the number of studies is restricted to

\footnotetext{
${ }^{7}$ For a review on efficiency studies which focus on specific areas of public goods provision, see e.g. Blank (2000); Worthington and Dollery (2000).
} 
a small sample of countries.

Vanden Eeckaut et al. (1993), De Borger et al. (1994), De Borger and Kerstens (1996a,b), and Geys and Moesen (2009), for example, focus on different aspects of the determinants of efficiency for the Belgian municipalities. Using a cross-section of 235 Walloon municipalities, Vanden Eeckaut et al. (1993) show that political majorities are an explanatory factor of the observed inefficiencies. By decomposing the efficiency scores obtained by a FDH- and DEA-analysis in different (political) categories, the authors show, that local governments run by nationwide parties are more efficient than local councils where other majorities are in power. A further result is that local governments with multiple-party coalitions are more efficient than municipalities governed by a single party. The focus of De Borger et al. (1994) and De Borger and Kerstens (1996a,b), on the other hand, is much broader. Similar to Vanden Eeckaut et al. (1993) they find - for a cross-section of all 589 Belgian municipalities - (weak) evidence that political characteristics influence local government efficiency. Moreover, they show that local tax rates and the level of education influence efficiency positively whereas (block) grants and (average) income is associated with lower efficiency levels. In all three studies the variations in efficiency among local governments are explained by a second-stage (Tobit) regression on the efficiency scores obtained in a first stage by several parametric and non-parametric estimation approaches. In contrast to the three above mentioned studies, the results of Geys and Moesen (2009) suggest that grants from higher level governments affect efficiency positively; they employ, however, the one-step approach proposed by Battese and Coelli (1995) for a cross-section of only the Flemish municipalities. According to the authors this (surprising) result could be due to the fact that grants from higher level governments in Flanders are linked to strict supervision on expenditures.

Balaguer-Coll et al. (2007) and Gimenez and Prior (2007) explore in a cross-sectional analysis the sources of efficiency of Spanish municipalities. While Gimenez and Prior (2007) explain the efficiency indices obtained in the first stage by means of a Tobit regression, Balaguer-Coll et al. (2007) use non-parametric smoothing techniques in the second stage. Both analyses support the findings of the above mentioned studies: Fiscal, political and educational variables are (significantly) related to local governments' efficiency. Similar results are also obtained by Afonso and Fernandes (2008), Athanassopoulos and Triantis (1998), Loikkanen and Susiluoto (2005), and Worthington (2000) for samples of local governments of Portugal, Greece, Finland, and Australia, respectively. All four studies share the common feature that they investigate the determinants of efficiency in a cross-sectional analysis (exception: Loikkanen and Susiluoto, 2005) by regressing the efficiency indices (obtained by DEA or stochastic frontier approaches in the first stage) on the potential determinants using Tobit or OLS regression techniques. 
In a further study, Borge et al. (2008) examine how the efficiency of Norwegian local governments is related to political and budgetary institutions, fiscal capacity, and democratic participation. They construct an efficiency measure which is defined as the ratio of an aggregate output indicator and local government revenue and regress this measure on a set of explanatory variables. The results of their study suggest that high fiscal capacity as well as a high degree of party fragmentation contribute to low efficiency; democratic participation, on the other hand, seems to influence efficiency positively. Furthermore, the authors find evidence that a centralised top-down budgetary procedure is associated with low efficiency.

Moreover, Grossman et al. (1999) investigate the technical efficiency of 49 U.S. cities by using an aggregate market value of residential homes and business property as an output indicator. By means of a stochastic frontier production function, which also includes the exogenous variables, the authors show that large cities in the United States are operating at (rather) different levels of technical efficiency and that the degree of technical inefficiency varies inversely with the measured levels of competitive pressures. Finally, Sung (2007) evaluates the performance of local governments in Korea. More specifically, the author focuses on the impact of information technology (IT) on the technical efficiency of the local governments. Using Data Envelopment Analysis and a second-stage Tobit regression, Sung (2007) shows that IT has a postive impact on the technical efficiency of the Korean local governments. Moreover, the results hint at the presence of economics of density in the production of local public services.

To sum up, the existing empirical literature on the determinants of local government efficiency employs in most cases efficiency indices as dependent variables which are obtained either by parametric or non-parametric estimation approaches. In contrast, there are only few studies which employ and compare both approaches (see e.g. De Borger and Kerstens, 1996a). Moreover, researchers mostly used the "traditional" two-stage approaches to investigate the determinants of local government efficiency; the one-step approach proposed by Battese and Coelli (1995) or the truncated regression along with the bootstrap correction proposed by Simar and Wilson (2007) have only been used in few investigations so far (see e.g. Geys and Moesen, 2009). However, as already shown in the previous section, the "traditional" two-stage approaches (in the context of parametric or non-parametric approaches) yield biased estimation results. Finally, the literature review reveals that there is no study that investigates the general determinants of the technical or cost efficiency (in the broadest sense) of the German local authorities. 


\section{Empirical Analysis}

Based on the methods derived in section 2, the following empirical analysis tries to investigate the main drivers of local government technical efficiency for the case of road maintenance. For this purpose, we make us of a broad panel of counties of the German state BadenWürttemberg. ${ }^{8}$ In our context, the German counties are an interesting case to study, since one of the main tasks of these counties is the construction and maintenance of county roads. However, before presenting the results along with the underlying data set, the institutional setting of the local governments as well as the main features of local road maintenance in Germany will be provided.

\subsection{Institutional Setting and Local Road Maintenance}

Germany is characterised by a federal structure, where the local governments constitute the lowest level of government. The local governments, in turn, can basically be divided into two administrative units: counties and municipalities, whereas the counties constitute the higher administrative level. More specifically, we can distinguish between rural (Landkreise) and urban (Stadtkreise) counties. The former are associations of a fixed number of municipalities, the latter consist of only one municipality (city) and are therefore county and municipality at the same time. ${ }^{9}$ Baden-Württemberg, the state considered here, consists of 35 rural and 9 urban counties. According to the German Basic Law (Grundgesetz) both administrative units (counties and municipalities) are guaranteed the right to local self-government (art. 28, para. 2). Therefore, counties as well as municipalities exhibit considerable autonomy on the revenue as well as the expenditure side. Since our data are based on a panel of German counties, we restrict our attention to the institutional setting of the counties (rather than municipalities) now.

According to Neser (2004), the counties have to perform three different types of tasks: (1) voluntary tasks like adult education centres or museum, (2) duties with instruction (from higher level governments) like the payment of housing benefit, and (3) duties without instruction like local public transport, waste disposal and the construction and maintenance of county roads, which is of main interest in the present analysis. The importance of this responsibility is stressed by the fact that the county road network in 2004 covered approximately 12.000 kilometres, which constitutes about $43 \%$ of the total road network ${ }^{10}$ outside of built-up areas in Baden-Württemberg.

\footnotetext{
${ }^{8}$ According to the NUTS-nomenclature established by Eurostat, the counties correspond to NUTS 3 regions.

${ }^{9}$ For more details, see Neser (2004)

${ }^{10}$ In Germany there are basically four different types of roads (with regard to the financing of the roads): roads that have to be financed (1) by the federal state (Bundesfernstraßen), (2) by the states (Landstraßen), (3) by the counties (Kreisstraßen), and (4) by the municipalities (Gemeindestraßen).
} 
Table 2: Revenues and expenditures of the (rural) counties in Euro per capita (1) and as a percentage of total revenues and total expenditures (2), respectively, for selected categories in 2004

\begin{tabular}{lcclcc}
\hline \hline Revenues & $(1)$ & $(2)$ & Expenditures & $(1)$ & $(2)$ \\
\hline Payments to counties & 211.70 & 38.72 & Social security & 174.80 & 31.83 \\
Allocation of funds & 143.82 & 26.31 & General financial management & 142.89 & 26.02 \\
User charges, fines, & & & Public facilities, business & & \\
reimbursement of costs & 107.95 & 19.75 & development & 62.62 & 11.40 \\
Borrowing $_{\text {Taxes }}^{23.77}$ & 4.35 & Schools & 57.81 & 10.53 \\
Other sources of revenue $^{a}{ }^{a}$ & 0.26 & 0.05 & General administration & 42.45 & 7.73 \\
& 59.20 & 10.83 & Public safety & 23.72 & 4.32 \\
& & & Architecture, housing, traffic & 22.31 & 4.06 \\
& & & Health, sport, recovery & 17.14 & 3.12 \\
& & & Science, research, culture & 3.88 & 0.71 \\
& & & Commercial companies, & & \\
& & & real and separate estate & 1.59 & 0.29 \\
\hline Sum & 546.70 & 100 & & 549.20 & 100 \\
\hline \hline
\end{tabular}

Source: Statistical Office of Baden-Württemberg, own calculations

${ }^{a}$ These include income from interest, shares in profit, concession levy, capital gains and cost-accounting depreciation

Table 2 shows the main income sources of the (rural) counties as well as the amount of money spent for the different types of tasks the counties face - per capita (1) and as a percentage of total revenues and total expenditures (2) for the year 2004. ${ }^{11}$ Looking first at the revenue structure, the table reveals that the counties basically have three main income sources: contributions, which have to be paid by the municipalities (Kreisumlage; 38.72\% of total revenues), allocation of funds (from the state level and from municipal equalisation schemes; $26.31 \%$ ) and income from user charges, fines and reimbursement of costs (19.75\%). More specifically, the size of the payments to the counties is based on a predetermined collection rate (Hebesatz) on the sum of the different (tax) revenues of the municipalities belonging to the county. ${ }^{12}$ The counties are able to levy theses contributions (from the municipalities) if the other revenues (user charges, allocations of funds,...) are not sufficient to cover cost. Therefore, the payments to the counties can be interpreted as a kind of "tax". ${ }^{13}$ Concerning (real) tax revenues, the counties impose only one tax on hunting. As can be seen from table 2, however, this tax is of minor importance ( $0.05 \%$ of total revenues). This is in sharp contrast to the municipalities (and urban counties) which can independently decide

\footnotetext{
${ }^{11}$ In table 2 we consider only rural counties, since there are differences between rural and urban counties concerning the revenue and expenditure structure. This is due to the fact that urban counties are county and municipality at the same time and therefore also have to represent municipal interests.

${ }^{12}$ Note that the collection rates can differ from county to county. In 2004 the average collection rate was $33.62 \%$.

${ }^{13}$ The difference between the payments to the counties and "usual" taxes is that the payments to the counties are not paid by the citizens (of the jurisdictions) themselves but by the municipal governments belonging to the counties.
} 
on five different types of taxes: trade tax, property tax and three bagatelle taxes (which are not levied by all municipalities).

Finally, turning to the expenditure side, table 2 also gives a detailed overview of the money spent for the different types of tasks (for the year 2004). As can be seen from the table, almost one third of the money is used for social security (31.83\% of total expenditures), but a major part is also spent on general financial management (i.e. mainly interest and amortization repayments; $26.02 \%$ ), public facilities and business development (11.40\%), schools (10.53\%) and general administration (7.73\%). Architecture, housing and traffic accounts for $4.06 \%$ of total expenditures. This also includes the construction and maintenance of (county) roads which approximately accounts for $3 \%$ of total expenditures. Moreover, public safety and health, sport and recovery constitute $4.32 \%$ and $3.12 \%$ of the total budget, respectively, whereas the last two posts on the budget (science, research and culture; commercial companies, real and separate estate) are of minor importance.

\subsection{Data}

As already mentioned at the beginning of this section, the empirical analysis is based on data for 44 counties of the German state Baden-Württemberg for the period of 1990 to 2004. Therefore, we end up with a sample of 660 observations. The descriptive statistics for all variables used in the analysis are given in table 3 below. ${ }^{14}$

As pointed out by De Borger and Kerstens (1996a), the definition of public sector inputs and outputs is difficult and fraught with data availability problems. But since we examine the main drivers of technical efficiency in a specific (here: road maintenance) rather than a global approach (like in De Borger and Kerstens, 1996a), potential sources of measurement errors are mitigated. More specifically, we follow Deller and Halstead (1994) and approximate the input necessary to construct and maintain the county roads by the total expenditures (for county roads). As can be seen from table 3, the expenditures for county roads show substantial variation within the sample used here.

Moreover, the output, that is the supply of roads to the populace, is measured by the area of the total road network which is under jurisdiction of the counties. Table 3 shows that the area of the county roads in the sample varies between approximately 12 and 350 hectare indicating that there are substantial variations among the counties. As a second output indicator, we include a variable which approximates not only the quantity but also the quality of the services provided. As pointed out by Balaguer-Coll et al. (2007) this is of great importance, since local governments often are not able to directly affect the quantity

\footnotetext{
${ }^{14}$ For more details on the sources of the data as well as the calculation of some of the variables, see Appendix
} A. 
Table 3: Descriptive Statistics

\begin{tabular}{|c|c|c|c|c|}
\hline Variable & Mean & Std. Dev. & "Min. & Max. \\
\hline \multicolumn{5}{|l|}{ Input variable: } \\
\hline $\begin{array}{l}\text { Total expenditures, county roads } \\
\text { (in mio. €) }\end{array}$ & 3.92 & 2.53 & 0.09 & 18.20 \\
\hline \multicolumn{5}{|l|}{ Output variables: } \\
\hline Area of county roads (in hectare) & 158.753 & 90.336 & 12.293 & 349.992 \\
\hline $\begin{array}{l}\text { Number of accidents due to bad } \\
\text { road conditions }\end{array}$ & 167.755 & 98.699 & 15 & 509 \\
\hline \multicolumn{5}{|l|}{ Exogenous variables (characteristics): } \\
\hline Unemployment rate (in \%) & 6.499 & 1.955 & 2.275 & 13.900 \\
\hline Population density (inhabitants per hectare) & 5.067 & 5.761 & 0.946 & 28.863 \\
\hline Rurality & 4.773 & 2.100 & 1 & 7 \\
\hline Total Population & 233296.80 & 122651.50 & 50891 & 598470 \\
\hline Accommodation facilities & 156.827 & 144.421 & 19 & 883 \\
\hline $\begin{array}{l}\text { Average (weighted) kilometres travelled on } \\
\text { county roads per year (in } 10000 \mathrm{~km} \text { ) }\end{array}$ & 2473.16 & 1489.25 & 217.63 & 8311.67 \\
\hline $\begin{array}{l}\text { Maximum geographical point of county } \\
\text { (in metre) }\end{array}$ & 637.29 & 225.34 & 146.51 & 1281.91 \\
\hline Urban county & 0.205 & 0.404 & 0 & 1 \\
\hline \multicolumn{5}{|l|}{ Exogenous variables (determinants): } \\
\hline Disposable income (in $€$ per capita) & 16413.27 & 1928.27 & 11836.23 & 23180.12 \\
\hline Payments to counties (in $€$ per capita) & 256.61 & 144.38 & 87.81 & 1065.81 \\
\hline Grants for county roads (in $€$ per capita) & 16.66 & 12.74 & 0 & 60.43 \\
\hline Herfindahl index & 0.295 & 0.040 & 0.217 & 0.413 \\
\hline Share of left & 31.090 & 7.623 & 10.714 & 50.000 \\
\hline
\end{tabular}

Sample size: 660 observations; 44 counties over 15 years (1990-2004). 
of outputs (at least in the short run), but have a decisive impact on their quality. As an indicator of the quality of the county roads we include the number of accidents caused by bad road conditions like potholes, ruts and so on. ${ }^{15}$ An increase in the number of accidents (meaning a deterioration in quality) is then expected to lower the costs for the provision of roads.

Since the purpose of this analysis is to investigate the determinants of technical efficiency (in road maintenance), the crucial part of the model refers to the inclusion of the exogenous variables. Concerning the characteristics of the counties we first include a measure which accounts for the volume of traffic on the county roads: the average (weighted) kilometres travelled on county roads per year. This indicator is calculated out of the sum of the kilometres travelled on county roads by motorcycles, cars and trucks with a maximum total weight of below and above 12 tons, whereas every of the four categories is given a special weight. Since higher traffic loads are associated with higher repair costs, we expect a positive relationship between costs and average kilometres travelled. In addition, to account for the geographical location of the county we include the maximum geographical point of the county. Then, the hypothesis is that counties located in more hilly regions have to spend comparatively more money on the construction and maintenance of roads since the development of the landscape is much more complicated (e.g. via bridges and tunnels).

The production environment is further accounted for through the inclusion of the population density and the total population (along with its squared value) of the counties. While a high population density points to cost advantages due to the regional concentration of the public services (see De Borger and Kerstens, 1996a), population density can also be regarded as a proxy for the heterogeneity of the property prices which usually tend be higher in more densely populated areas. Therefore, the influence of population density on the level of the counties' expenditures is ambiguous. On the other hand, total population is included to control for potential (dis)economies of scale (see Geys and Moesen, 2009), that is expenditures are assumed to increase with total population. We further include an index of rurality to the estimation specification; this index splits the counties (of Germany) in three different categories: (1) agglomeration areas, (2) urbanised areas, and (3) rural areas. Moreover, within every group, there are up to four different classes differing in population size as well as population density. Altogether, there are nine different types of counties, whereas a higher number indicates a higher degree of "rurality". ${ }^{16}$ Therefore, this index captures not only

\footnotetext{
${ }^{15}$ Note that this variable also contains accidents caused by other bad road conditions (e.g. by slippery roads). Unfortunately, a more detailed indicator was not available. In addition, the number of accidents caused by bad road conditions were available only for the total road network. But given the fact that county roads constitute $43 \%$ of the total road network (outside of built-up areas) in Baden-Württemberg (see subsection 4.1) this is a minor problem.

${ }^{16}$ For more details on the classification of the counties, see Appendix A
} 
information about population size and population density, it also provides information about the sphere of influence of supra-regional cities. Since property prices usually tend to be lower in rural areas, an increase in this index (that is a higher degree of rurality) is expected to lower costs. ${ }^{17}$

Moreover, to control for economic shocks, the local unemployment rate is included to the model. As pointed out by Geys et al. (2008), the unemployment rate can affect spending in two opposite directions, since it implies both higher spending on unemployment benefits (like housing benefit; "cost effect") and lower demand for high quality public services ("preference effect"). Therefore, the effect of the level of the unemployment rate on expenditures is ambiguous. In addition, counties located in touristic regions (like the Black Forest or the region around Lake Constance) have to spend more money on public services, since tourists usually demand higher-cost or higher-quality services (see Sampaio De Sousa and Stosic, 2005; Kalb, 2008). For this reason, the total number of the counties' accommodation facilities (that is, guesthouses of all forms) was included to the model. An increase in the number of accommodation facilities is then expected to rise costs.

Apart from the characteristics of the counties we are also (and mainly) interested in the determinants of technical efficiency. Regarding this, we firstly include the per capita disposable income of the counties' citizens, since "it is well known that incomes and wealth of citizens affect the incentives of both politicians and taxpayers to monitor expenditures" (De Borger and Kerstens, 1996a, p. 162). Higher income levels increase the fiscal capacity and therefore may foster potential inefficiencies (by the incumbents). In addition, the motivation of high-income citizens to monitor incumbents could be relatively low due to higher opportunity costs. On the other hand, as argued by Knack (2002), high-income citizens are more educated and might therefore be more effective in demanding more efficient governments. For this reason, the effect of the per capita disposable income on technical efficiency is ambiguous.

Second, we included variables to the specification that account for the financing of the provision of the public goods and services (here: county roads). As pointed out by De Borger and Kerstens (1996a), higher tax burdens may increase the awareness of the citizens how public funds are used. This, in turn, could lead to an increase in the monitoring activities of the populace and therefore to a decrease in the budgetary slack (or inefficiency). Moreover, recent studies for Germany and Belgium found evidence for significant (tax) competition effects between local jurisdictions (see Buettner, 2001; Geys, 2006). One possibility to reduce the tax rates (due to higher tax competition), is to remove or at least to reduce potential

\footnotetext{
${ }^{17}$ Note that Baden-Württemberg, the state considered here, consists only of agglomeration as well as urbanised areas (see table 3). This is due to the fact that Baden-Würrtemberg is one of the more industrialised states in Germany.
} 
inefficiencies. To proxy for the above mentioned effects, the payments to the counties - which can be interpreted as a kind of tax levied by the counties (see also subsection 4.1) - are included to the specification. ${ }^{18}$ Besides the autonomously raised revenue, the counties also receive (intergovernmental) grants (see subsection 4.1). From the literature on the flypaper effect (for a review, see e.g. Hines and Thaler, 1995) it is well known, that money obtained from lump-sum grants is differently used than money which originates from own income sources. Numerous studies showed that unconditional grants stimulate spending by much more than economic theory predicts. Recently, Kalb (2008) showed for a sample of German municipalities that a higher degree of redistribution within a system of fiscal equalisation fosters the incentives of the incumbents to extend organisational slack (or inefficiency). Using data on libraries and school bus transportation, Silkman and Young (1982) came to similar conclusions for the United States. Therefore it is hypothesised that technical efficiency decreases with the amount of grants. To take account of theses effects we added the per capita grants for county roads to the specification.

In addition, political variables are included to the model, since there are a number of reasons why politicians may lack proper incentives to effectively monitor and control public spending (see e.g. Mueller, 2003). First, we introduce a Herfindahl index which measures the political concentration or monopolisation of the county council (Kreistag). This index is calculated using the seat shares of the main national parties (from right to left: CDU, FDP, SPD and GRÜNE) and of the so-called "free voters unions" in the county council. ${ }^{19}$ Then, high political concentration is associated with lower efficiency levels since high political concentration involves low political competition (see e.g. Besley et al., 2005). Second, we include a variable which measures the impact of ideology on technical efficiency: the share of seats of the left-wing parties (that is SPD and GRÜNE) in the county council. As pointed out by Geys et al. (2008), however, the relationship between ideology and (technical) efficiency is not easy to determine a priori. Indeed, left-wing parties are often associated with preferences for higher spending, a larger government size, however, does not necessarily imply lower levels of efficiency. Therefore, the sign of the variable share of left is ambiguous.

Finally, we include a dummy variable for urban counties as well as a time trend to control for time effects in the stochastic frontier as well as in the (second-stage) inefficiency model.

\footnotetext{
${ }^{18}$ Since the urban counties do not receive payments from municipalities (because they are county and municipality at the same time), we took the revenue from the trade tax to proxy the (main) income source of the urban counties.

${ }^{19}$ Free voters unions are loose federations of persons that do not belong to specific political parties and exist only at the local level.
} 


\subsection{Results}

The results of the different estimation approaches are shown in the following two tables: In table 4 we present the results of the one-step procedure proposed by Battese and Coelli (1995) (columns 1 and 2) as well as the results of the two-step procedure (columns 3 and 4), where according to equation (3) - in a first stage ${ }^{20}$ efficiency scores are estimated, and, afterwards, the efficiency estimates obtained in the first stage are regressed on the exogenous variables in a pooled OLS regression. On the other hand, the effects of the exogenous variables on DEAbased efficiency estimates are shown in table 5, whereas the results of the Tobit regression are given in columns 1 and 2 and the results of the truncated regression with the bootstrap corrected t-values proposed by Simar and Wilson (2007) (see subsection 2.2) are shown in columns 3 and 4 . Note that in table 4 (5) a positive signs means inefficiency (efficiency) enhancing and vice versa. ${ }^{21}$

Before starting with the discussion of the (main) determinants of efficiency, we first consider the estimation results of the stochastic frontier in the one-step approach proposed by Battese and Coelli (1995) in table 4. As expected, the area of the county roads has a positive and highly statistically significant impact on total expenditures for county roads. However, the impact of our second output variable, the number of accidents due to bad road conditions approximating the quality of the county roads, is - contrary to our predictions - positive and not statistically significant. This could be due to the fact that county roads (in Baden-Württemberg) are (generally) in good condition (see Neser, 2004, p. 75) and therefore quality is of minor importance. Finally, note that a likelihood ratio test of the translogarithmic against the Cobb-Douglas functional form rejected the Cobb-Douglas function at the one percent level indicating that the (more flexible) translograrithmic model (used here) seems to be more appropriate.

Turning now to the discussion of the impact of the exogenous variables on technical efficiency, table 4 and 5 illustrate that it is first important to account for the characteristics and the production environment of the counties. More specifically, we first observe the desired positive relationship between the average (weighted) kilometres travelled on county roads and costs (due to higher costs of wear on much frequented roads) in all four specifications. Second, total population also shows a positive relationship, the coefficients of the full specifications are, however, insignificant (exception: specification (3) in table 5). But this changes

\footnotetext{
${ }^{20}$ For the results of the first-stage stochastic frontier regression, see table B1, Appendix B.

${ }^{21}$ The differences in the interpretation of the signs in table 4 and 5 are due to the fact that either the efficiency scores (lying between 0 and 1) or their reciprocals (lying between 1 and $\infty$ ) can be used as independent variables in the (second-stage) regression. We used both values as independent variables (for the non-parametric as well as the parametric efficiency estimates) and chose those models with the highest adjusted pseudo- $R^{2}$. The results of the (two) remaining models, however, are very similar and are available upon request.
} 
Table 4: Determinants of the counties' efficiency in road maintenance (parametric approach)

\begin{tabular}{|c|c|c|c|c|}
\hline \multirow[t]{2}{*}{ Variable } & \multicolumn{2}{|c|}{ One-step approach } & \multicolumn{2}{|c|}{ Two-step ap proach } \\
\hline & $(1)$ & $(2)$ & $(3)$ & $(4)$ \\
\hline \multicolumn{5}{|c|}{ Stochastic Frontier } \\
\hline Constant & $\begin{array}{l}7.1211^{* *} \\
(7.9024)\end{array}$ & $\begin{array}{l}6.9312^{* *} \\
(8.7659)\end{array}$ & - & - \\
\hline A: Area of county roads, log & $\begin{array}{l}2.1229^{* *} \\
(7.7885)\end{array}$ & $\begin{array}{l}2.1314^{* *} \\
(8.3122)\end{array}$ & - & - \\
\hline $\begin{array}{l}\text { B: Number of accidents due to } \\
\text { bad road conditions, log }\end{array}$ & $\begin{array}{l}0.1236 \\
(0.3903)\end{array}$ & $\begin{array}{c}0.1839 \\
(0.6158)\end{array}$ & - & - \\
\hline $\mathrm{A}^{2}$ & $\begin{array}{c}-0.0744^{* *} \\
(-2.6651)\end{array}$ & $\begin{array}{r}-0.0780^{* *} \\
(-2.7918)\end{array}$ & - & - \\
\hline $\mathrm{B}^{2}$ & $\begin{array}{c}0.0488 \\
(1.3153)\end{array}$ & $\begin{array}{c}0.0385 \\
(1.0082)\end{array}$ & - & - \\
\hline$A^{*} \mathrm{~B}$ & $\begin{array}{c}-0.1083^{* *} \\
(2.6819) \\
\end{array}$ & $\begin{array}{r}-0.1017^{* *} \\
(-2.4916) \\
\end{array}$ & - & - \\
\hline \multicolumn{5}{|c|}{ Inefficiency model (Characteristics) } \\
\hline Constant & $\begin{array}{c}-4.7219^{* *} \\
(-4.2076)\end{array}$ & $\begin{array}{r}-4.7360^{* *} \\
(-5.0769)\end{array}$ & $\begin{array}{r}-1.5401^{* *} \\
(-3.2867)\end{array}$ & $\begin{array}{c}-1.9231^{* *} \\
(-4.3698)\end{array}$ \\
\hline Urban county & $\begin{array}{c}0.9417^{* *} \\
(2.2227)\end{array}$ & $\begin{array}{c}0.8531^{* *} \\
(2.4620)\end{array}$ & $\begin{array}{c}0.4833^{* *} \\
(3.0287)\end{array}$ & $\begin{array}{c}0.5640^{* *} \\
(3.4295)\end{array}$ \\
\hline Unemployment rate & $\begin{array}{c}0.0322 \\
(1.0375)\end{array}$ & $\begin{array}{c}0.0018 \\
(0.0573)\end{array}$ & $\begin{array}{c}0.0359^{* *} \\
(3.1544)\end{array}$ & $\begin{array}{c}0.0260^{* *} \\
(2.2826)\end{array}$ \\
\hline Population density & $\begin{array}{l}-0.0213 \\
(-0.9785)\end{array}$ & $\begin{array}{l}-0.0364^{*} \\
(-1.6933)\end{array}$ & $\begin{array}{c}-0.0152 \\
(-1.2673)\end{array}$ & $\begin{array}{r}-0.0296^{* *} \\
(-2.5379)\end{array}$ \\
\hline Population, 1000 & $\begin{array}{c}0.0025 \\
(0.9104)\end{array}$ & $\begin{array}{c}0.0068^{* *} \\
(3.2438)\end{array}$ & $\begin{array}{c}0.0017 \\
(1.5959)\end{array}$ & $\begin{array}{c}0.0044^{* *} \\
(5.8578)\end{array}$ \\
\hline Population, squared & $\begin{array}{l}-0.0000^{* *} \\
(-2.0203)\end{array}$ & $\begin{array}{r}-0.0000^{* *} \\
(-4.1837)\end{array}$ & $\begin{array}{r}-0.0000^{* *} \\
(-3.5822)\end{array}$ & $\begin{array}{r}-0.0000^{* *} \\
(-6.8122)\end{array}$ \\
\hline Rurality & $\begin{array}{l}-0.0078 \\
(-0.2405)\end{array}$ & $\begin{array}{l}-0.0235 \\
(-0.8356)\end{array}$ & $\begin{array}{l}-0.0003 \\
(-0.0191)\end{array}$ & $\begin{array}{l}-0.0018 \\
(-0.1058)\end{array}$ \\
\hline Accommodation facilities & $\begin{array}{c}0.0019^{* *} \\
(4.5316)\end{array}$ & $\begin{array}{c}0.0018^{* *} \\
(4.0033)\end{array}$ & $\begin{array}{c}0.0007^{* *} \\
(8.2450)\end{array}$ & $\begin{array}{c}0.0007^{* *} \\
(7.7510)\end{array}$ \\
\hline $\begin{array}{l}\text { Kilometres travelled on } \\
\text { county roads per year }\end{array}$ & $\begin{array}{l}0.0001^{* *} \\
(2.9242)\end{array}$ & - & $\begin{array}{l}0.0001^{* *} \\
(4.0984)\end{array}$ & - \\
\hline $\begin{array}{l}\text { Maximum geographical } \\
\text { point of county }\end{array}$ & $\begin{array}{c}-0.0024^{* *} \\
(-5.5501) \\
\end{array}$ & $\begin{array}{c}-0.0024^{* *} \\
(-5.6848) \\
\end{array}$ & $\begin{array}{r}-0.0010^{* *} \\
(-7.4878) \\
\end{array}$ & $\begin{array}{c}-0.0011^{* *} \\
(-7.9423) \\
\end{array}$ \\
\hline \multicolumn{5}{|c|}{ Inefficiency model (Determinants) } \\
\hline Disposable income & $\begin{array}{c}0.0003^{* *} \\
(4.9534)\end{array}$ & $\begin{array}{c}0.0003 \\
(6.1223)\end{array}$ & $\begin{array}{c}0.0002^{* *} \\
(7.0494)\end{array}$ & $\begin{array}{c}0.0002^{* *} \\
(8.5207)\end{array}$ \\
\hline Payments to counties & $\begin{array}{c}0.0012^{* *} \\
(2.2507)\end{array}$ & $\begin{array}{c}0.0014^{* *} \\
(2.7656)\end{array}$ & $\begin{array}{c}0.0009 \\
(1.6353)\end{array}$ & $\begin{array}{l}0.0011^{*} \\
(1.9048)\end{array}$ \\
\hline Grants for county roads & $\begin{array}{c}0.0204^{* *} \\
(3.4508)\end{array}$ & $\begin{array}{c}0.0205^{* *} \\
(4.2292)\end{array}$ & $\begin{array}{l}0.0039^{*} \\
(1.8375)\end{array}$ & $\begin{array}{c}0.0063^{* *} \\
(3.0057)\end{array}$ \\
\hline Herfindahl index & $\begin{array}{c}0.0985 \\
(0.1065)\end{array}$ & $\begin{array}{c}-0.5282 \\
(-0.5907)\end{array}$ & $\begin{array}{l}0.8959^{*} \\
(1.9191)\end{array}$ & $\begin{array}{c}0.6413 \\
(1.3398)\end{array}$ \\
\hline Share of left & $\begin{array}{c}-0.0124 \\
(-1.2819) \\
\end{array}$ & $\begin{array}{c}-0.0135 \\
(-1.3219) \\
\end{array}$ & $\begin{array}{l}0.0062^{*} \\
(1.8495) \\
\end{array}$ & $\begin{array}{c}0.0051 \\
(1.5357) \\
\end{array}$ \\
\hline Sigma-squared $\left(\hat{\sigma}^{2}\right)$ & $\begin{array}{l}0.2121^{* *} \\
(10.1179)\end{array}$ & $\begin{array}{c}0.2089^{* *} \\
(10.4461)\end{array}$ & - & - \\
\hline $\operatorname{Gamma}(\gamma)$ & $\begin{array}{c}0.6360^{* *} \\
(14.9942)\end{array}$ & $\begin{array}{c}0.6327^{* *} \\
(13.2922)\end{array}$ & - & - \\
\hline Log-likelihood & -223.47 & -228.42 & - & - \\
\hline Adjusted $R^{2}$ & - & - & 0.45 & 0.44 \\
\hline
\end{tabular}

Note: $\mathrm{N}=660$. Dependent variable of (1) and (2): total expenditures for county roads; dependent variable of (3) and (4): efficiency scores obtained from the stochastic frontier regression of total expenditures for county roads on the output variables (for the results see Appendix B). All specifications include time fixed effects. (Robust) t-values are given in parentheses. ${ }^{* *}(*)$ denotes significance at the $5 \%(10 \%)$ level. 
Table 5: Determinants of the counties' efficiency in road maintenance (non-parametric approach)

\begin{tabular}{|c|c|c|c|c|}
\hline \multirow[t]{2}{*}{ Variable } & \multicolumn{2}{|c|}{ Tobit } & \multicolumn{2}{|c|}{ "Truncated Regression } \\
\hline & (1) & $(2)$ & $(3)$ & $(4)$ \\
\hline \multicolumn{5}{|c|}{ Characteristics } \\
\hline Constant & $\begin{array}{l}2.1324^{* *} \\
(6.9752)\end{array}$ & $\begin{array}{l}2.2508^{* *} \\
(7.5084)\end{array}$ & $\begin{array}{c}1.5066^{* *} \\
(5.2927)\end{array}$ & $\begin{array}{l}1.0259^{* *} \\
(4.0725)\end{array}$ \\
\hline Urban county & $\begin{array}{r}0.4797^{* *} \\
(5.7538)\end{array}$ & $\begin{array}{l}0.4559^{* *} \\
(5.5268)\end{array}$ & $\begin{array}{r}-0.2699^{* *} \\
(-3.5922)\end{array}$ & $\begin{array}{r}-0.4243^{* *} \\
(-7.2205)\end{array}$ \\
\hline Unemployment rate & $\begin{array}{l}-0.0097 \\
(-1.3481)\end{array}$ & $\begin{array}{c}-0.0068 \\
(-0.9704)\end{array}$ & $\begin{array}{l}0.0167^{* *} \\
(2.4348)\end{array}$ & $\begin{array}{l}0.0127^{*} \\
(1.8666)\end{array}$ \\
\hline Population density & $\begin{array}{r}-0.0281 * * \\
(-4.6153)\end{array}$ & $\begin{array}{r}-0.0238^{* *} \\
(-4.2338)\end{array}$ & $\begin{array}{c}0.0020 \\
(0.3664)\end{array}$ & $\begin{array}{r}0.0117^{* *} \\
(3.0304)\end{array}$ \\
\hline Population, 1000 & $\begin{array}{l}-0.0000 \\
(-0.0679)\end{array}$ & $\begin{array}{l}-0.0009^{*} \\
(-1.7905)\end{array}$ & $\begin{array}{c}-0.0021^{* *} \\
(-3.5108)\end{array}$ & - \\
\hline Population, squared & $\begin{array}{l}0.0000 \\
(1.4735)\end{array}$ & $\begin{array}{l}0.0000^{* *} \\
(3.0055)\end{array}$ & $\begin{array}{c}0.0000^{* *} \\
(3.7516)\end{array}$ & - \\
\hline Rurality & $\begin{array}{c}0.0277^{* *} \\
(3.3865)\end{array}$ & $\begin{array}{l}0.0281^{* *} \\
(3.4389)\end{array}$ & $\begin{array}{c}0.0011 \\
(0.1495)\end{array}$ & $\begin{array}{c}0.0064 \\
(0.9039)\end{array}$ \\
\hline Accommodation facilities & $\begin{array}{r}-0.0003^{* *} \\
(-3.9319)\end{array}$ & $\begin{array}{r}-0.0003^{* *} \\
(-3.8892)\end{array}$ & $\begin{array}{l}-0.0000 \\
(-0.4041)\end{array}$ & $\begin{array}{c}-0.0001 \\
(-0.6503)\end{array}$ \\
\hline $\begin{array}{l}\text { Kilometres travelled on } \\
\text { county roads per year }\end{array}$ & $\begin{array}{l}-0.0000^{*} \\
(-1.8300)\end{array}$ & - & $\begin{array}{c}0.0000 \\
(1.5929)\end{array}$ & $\begin{array}{l}-0.0000 \\
(-0.6727)\end{array}$ \\
\hline $\begin{array}{l}\text { Maximum geographical } \\
\text { point of county }\end{array}$ & $\begin{array}{c}0.0001 \\
(1.6043)\end{array}$ & $\begin{array}{l}0.0001^{*} \\
(1.9135)\end{array}$ & $\begin{array}{c}0.0002^{* *} \\
(2.9096)\end{array}$ & $\begin{array}{r}0.0002^{* *} \\
(2.8969)\end{array}$ \\
\hline \multicolumn{5}{|c|}{ Determinants } \\
\hline Disposable income & $\begin{array}{r}-0.0001^{* *} \\
(-5.7411)\end{array}$ & $\begin{array}{r}-0.0001^{* *} \\
(-6.6078)\end{array}$ & $\begin{array}{c}-0.0000^{* *} \\
(-3.9483)\end{array}$ & $\begin{array}{l}-0.0000^{* *} \\
(-3.5872)\end{array}$ \\
\hline Payments to counties & $\begin{array}{c}-0.0002 \\
(-1.1289)\end{array}$ & $\begin{array}{c}-0.0003 \\
(-1.3859)\end{array}$ & $\begin{array}{l}-0.0001 \\
(-0.8602)\end{array}$ & $\begin{array}{c}-0.0001 \\
(-0.5370)\end{array}$ \\
\hline Grants for county roads & $\begin{array}{r}-0.0050^{* *} \\
(-3.4220)\end{array}$ & $\begin{array}{r}-0.0058^{* *} \\
(-4.0624)\end{array}$ & $\begin{array}{c}-0.0084^{* *} \\
(6.3586)\end{array}$ & $\begin{array}{r}-0.0072^{* *} \\
(-6.0786)\end{array}$ \\
\hline Herfindahl index & $\begin{array}{c}-0.3562 \\
(-1.0632)\end{array}$ & $\begin{array}{l}-0.2849 \\
(-0.8543)\end{array}$ & $\begin{array}{c}0.0034 \\
(0.0108)\end{array}$ & $\begin{array}{c}0.3704 \\
(1.1681)\end{array}$ \\
\hline Share of left & $\begin{array}{r}-0.0093^{* *} \\
(-3.9676) \\
\end{array}$ & $\begin{array}{c}-0.0090^{* *} \\
(-3.8356) \\
\end{array}$ & $\begin{array}{l}-0.0041^{*} \\
(-1.8931) \\
\end{array}$ & $\begin{array}{c}-0.0058^{* *} \\
(-2.6891) \\
\end{array}$ \\
\hline$\hat{\sigma}_{\epsilon}$ & $\begin{array}{c}0.2486^{* *} \\
(31.1859)\end{array}$ & $\begin{array}{c}0.2492^{* *} \\
(31.1815)\end{array}$ & $\begin{array}{c}0.3099^{* *} \\
(58.8598)\end{array}$ & $\begin{array}{c}0.3128^{* *} \\
(59.4877)\end{array}$ \\
\hline Log-likelihood & -143.42 & -145.09 & -70.82 & -81.65 \\
\hline Adjusted Pseudo- $R^{2}$ & 0.30 & 0.30 & - & - \\
\hline
\end{tabular}

Note: $\mathrm{N}=660$. Dependent variable: efficiency indices obtained using DEA. All specifications include time fixed effects. t-values are given in parentheses. The efficiency indices and t-values of specification (3) and (4) are corrected by the bootstrap procedure ("algorithm 2") proposed by Simar and Wilson (2007) (see also subsection 2.2). ** $\left(^{*}\right.$ ) denotes significance at the $5 \%(10 \%)$ level. 
once the variable "kilometres travelled on county roads" is removed from the model (see specifications (2) and (4) of table 4 and specifications (2) of table 5). This could be due to the fact that the kilometres travelled are a substitute for total population. ${ }^{22}$ Third, the influence of population density on costs is not clear; indeed, three of the four specifications hint at cost advantages form agglomeration economies (see table 4 and specifications (3) and (4) of table 5), the significance of the coefficients among the specifications is, however, not very robust. Fourth, the coefficient of the index of rurality shows the desired sign in all four specifications, the coefficients are, however, only statistically significant in the Tobit regression of table 5 .

Fifth, an increasing number of accommodation facilities is accompanied by rising costs; this effect is (mostly) highly statistically significant and supports the hypothesis of Sampaio De Sousa and Stosic (2005) and Kalb (2008) that touristic regions have a greater demand for high-cost or high-quality services. Sixth, concerning the unemployment rate, three of the four specifications show a negative relationship between the unemployment rate and costs; only the truncated regression in table 5 points to the inverse relationship. Therefore, we carefully conclude that the cost effect (i.e. higher spending for unemployment benefits) outweighs the preference effect (i.e. lower demand for high-quality public services). Finally, the maximum geographical point of the counties which accounts for the geographical location of the counties has - contrary to our predictions in subsection 4.2 - a positive impact on costs. One explanation for this (surprising) result could be the fact that this variable approximates the differences in road construction and maintenance between rural and urban areas (rather than just the geographical location of the counties), because (more densely populated) urban areas are more often located in flat regions. Since in urban areas bypasses (i.e. highways that redirect traffic around urban areas) are more often needed than in (hilly) rural areas, and since bypasses often include the construction and maintenance of expensive bridges and tunnels, the expenditures for (county) roads are much higher in urban areas.

Furthermore, concerning the determinants of technical efficiency, which are of main interest in this study, we first find that the disposable income of the citizens significantly reduces (technical) efficiency in all four specifications. This (very) robust result is in accordance with the findings of De Borger and Kerstens (1996a) and strongly supports the hypotheses that (1) higher income levels foster potential inefficiencies, since they increase the fiscal capacity of the counties, and (2) the monitoring activities of high-income citizens are (comparatively) lower since opportunity costs are higher.

Second, the payments to the counties have - contrary to our predictions - a negative,

\footnotetext{
${ }^{22}$ Note that in the truncated regression of table 5, total population (along with its squared term) was removed to get a negative coefficient (which, however, is insignificant) for the kilometres travelled on county roads.
} 
and in the parametric approach (see table 4) also a (highly) significant impact on technical efficiency. One of the arguments brought forward for a positive relationship between the payments to the counties and (technical) efficiency in subsection 4.2 was that higher tax burdens increase the awareness of the local jurisdictions' citizens how public funds are used and therefore also increase monitoring activities. Since the (rural) counties consist of different municipalities which, in turn, levy own taxes (e.g. trade and property tax), the populace of the different municipalities may be more intent on monitoring the incumbents of their own municipalities (than those of the counties) because they may think that other citizens of other municipalities (belonging to the same county) will monitor the incumbents of the counties. In other words, the monitoring mechanism on the county level may fail. This, however, increases the possibilities for the counties' incumbents to rise budgetary slack (or inefficiency). Third, table 4 and 5 show that the grants for the county roads reduce (technical) efficiency. Moreover, this effect is highly statistically significant in all four specifications. This (very) robust result is in accordance with the findings of Silkman and Young (1982) and Kalb (2008) and supports the hypothesis that intergovernmental grants stimulate the incentives of the local jurisdictions' incumbents to extend budgetary slack.

Finally, turning to the political variables, we find that the impact of the Herfindahl index - measuring the political concentration or monopolisation of the county council - on (technical) efficiency is unclear. While the Tobit regression and the two-step approach hint at a negative relationship between political concentration and efficiency, the truncated regression point to the inverse relationship; the two specifications of the one-step approach even yield different results. Moreover, almost all coefficients are insignificant. Therefore, we find no clear evidence for the hypothesis, that (technical) efficiency increases with political monopolisation in the local council (set up in subsection 4.2). Concerning the ideology measure ("share of left"), three of the four specifications show a negative and statistically significant relationship between the share of the left-wing parties in the county council and (technical) efficiency. Only the one-step approach of Battese and Coelli (1995) in table 5 points to the inverse relationship; the coefficients are, however, insignificant. Therefore, we carefully conclude that local governments with a higher share of left-wing parties seems to be associated with higher inefficiency.

\section{Conclusions}

In this paper we investigate the determinants of local government efficiency for the case of local road maintenance for a panel of German counties using a broad variety of estimation approaches. For this purpose we calculate efficiency indices using non-parametric (DEA) 
and parametric (stochastic frontier analysis) reference technologies, and examine how these efficiency indices can be explained by a number of exogenous (e.g. socio-economic, fiscal, political) variables. More specifically, we apply and compare four different estimation approaches to detect the potential sources of (in)efficiency: In case of the efficiency estimates obtained by stochastic frontier analysis we apply (1) the two-step approach and (2) the onestep approach proposed Battese and Coelli (1995); the DEA-based efficiency estimates are analysed (3) in a second-step Tobit regression as well as (4) in a truncated regression where the t-values are corrected by the bootstrap procedure proposed by Simar and Wilson (2007).

The results of the analysis can be summarised as follows: The disposable income of the counties' citizens, intergovernmental grants (for county roads), and the payments to the counties were estimated to influence (technical) efficiency negatively. Concerning political variables we found weak evidence that (technical) efficiency decreases with an increasing share of seats of left-wing parties in the county council; on the other hand, the hypothesis that (technical) efficiency decreases with the degree of political concentration in the county council could not be confirmed. In addition, concerning the characteristics of the counties, we show that costs increase with population size, the kilometres travelled on county roads per year (accounting for the volume of traffic on the county roads), and the number of accommodation facilities (approximating the degree of the regions' tourism), whereas the effect of population density is ambiguous across the different estimation specifications. Moreover, we found weak evidence for a positive relationship between the unemployment rate and costs. Finally, costs decrease with the degree of rurality of the counties as well as the maximum geographical point of the county (accounting for the geographical location of the counties).

Furthermore, the analysis shows, that not all of the four estimation approaches (mentioned above) are consistent - concerning the sign of the coefficients as well as the (statistical) significance. Therefore, focusing on just one estimation method (e.g. DEA + Tobit regression), as it was done in the most previous studies investigating the determinants of local governments' technical efficiency, may be deceptive. To test the robustness of the results, different estimation approaches should be applied and compared. In addition, useful policy implications can be drawn from this analysis. Firstly, the negative relationship between the grants and technical efficiency points out that the arrangement of the intergovernmental grants is important with regard to efficiency considerations. As put forward by Silkman and Young (1982), this may suggest the need "to include explicit productivity clauses and performance incentives [in grant-in-aid formulas] which link efficiency or productivity with the levels of payments" (p. 395). On the other hand, Kalb (2008) suggests that local governments should be given more autonomy in raising their own revenue, since this could reduce fiscal illusion (which may be one source of technical inefficiency). Secondly, as mentioned in subsection 
4.3, the negative relationship between the payments to the counties and technical efficiency suggests that there is a failure in the monitoring mechanism (of the citizens) on the county level. Similar to the intergovernmental grants, proxies for the efficiency of the counties could be incorporated into the design mechanism of the payments to the counties to minimise potential inefficiencies.

Finally, it should be noted that some of the explanatory variables used in this analysis may suffer from an endogeneity bias or, more specifically, from reverse causality. Of course, a suitable technique to overcome this problem would be the usage of instrumental variable (IV) estimation techniques. However, the methods employed here do not allow to introduce such an estimation approach; certainly, it would be interesting to redo this analysis with an instrumental variable estimation technique. In addition, it should be kept in mind that, despite of the usage of a specific (namely road maintenance) rather than a global approach, the output and input indicators are only proxies of the "real" outputs and inputs. Nevertheless, the usage of a specific rather than a global approach considerably reduces potential sources of measurement errors (in the inputs and outputs). To further minimise potential sources of error, the determinants of technical efficiency may be analysed not only for one particular area of local public good provision (like road maintenance) but simultaneously for different areas like waste collection, administration, and so on. A high degree of consistency in the results of the different models (e.g. in the signs of the explanatory variables) then points to robust results. But this is left for future research. 


\section{References}

Afonso, A. And S. Fernandes (2008): "Assessing and Explaining the Relative Efficiency of Local Government," Journal of Socio-Economics, 37, 1946-1979.

Aigner, D., C. Lovell, And P. Schmidt (1977): "Formulation and Estimation of Stochastic Frontier Production Function Models," Journal of Econometrics, 6, 21-37.

Athanassopoulos, A. And K. Triantis (1998): "Assessing Aggregate Cost Efficiency and the Related Policy Implications for Greek Local Municipalities," Infor, 36, 66-83.

Balaguer-Coll, M., D. Prior, And E. Tortosa-Ausina (2007): "On the Determinants of Local Government Performance: A Two-Stage Nonparametric Approach," European Economic Review, 51, 425-451.

Banker, R., A. Charnes, And W. Cooper (1984): "Some Models for Estimating Technical and Scale Inefficiencies in Data Envelopmemnt Analysis," Management Science, 30, 1078-1092.

Battese, G. And T. Coelli (1995): "A Model for Technical Inefficiency Effects in a Stochastic Frontier Production Function for Panel Data," Empirical Economics, 20, 325332.

Besley, T., T. Persson, and D. Sturm (2005): "Political Competition and Economic Performance: Theory and Evidence from the United States," NBER Working Paper, No. 11484

Blank, J. (2000): Public Provision and Performance - Conntributions from Efficiency and Productivity Measurement, Amsterdam: North Holland.

Borge, L.-E., T. Falch, And P. Tovmo (2008): "Public Sector Efficiency: The Roles of Political and Budgetary Institutions, Fiscal Capacity and Democratic Participation," Public Choice, 136, 475-495.

Buettner, T. (2001): "Local business taxation and competition for capital: the choice of the tax rate," Regional Science and Urban Economics, 31, 215-245.

Charnes, A., W. Cooper, And E. Rhodes (1978): "Measuring the Efficiency of Decision Making Units," European Journal of Operational Research, 2, 429-444.

Chicoine, D., S. Deller, And N. Walzer (1989): "The Size Efficiency of Rural Governments: The Case of Low-Volume Rural Roads," Publius: The Journal of Federalism 19, 19, 127-138. 
Christensen, L., D. Jorgenson, And L. LaWrence (1973): "Transcendental Logarithmic Production Frontiers," Review of Economics and Statistics, 55, 28-45.

De Borger, B. And K. Kerstens (1996a): "Cost Efficiency of Belgian Local Governments: A Comparative Analysis of FDH, DEA and Econometric Approaches," Regional Science and Urban Economics, 26, 145-170.

- (1996b): "Radial and Nonradial Measures of Technical Efficiency: An Empirical Illustration for Belgian Local Governments Using and FDH Reference Technology," Journal of Productivity Analysis, 7, 41-62.

(2000): "What is Known About Municipal Efficiency? The Belgian Case and Beyond," in Public Provision and Performance: Contributions from Efficiency and Productivity Measurement, ed. by J. Blank, Amsterdam: Elsevier, 299-330.

De Borger, B., K. Kerstens, W. Moesen, And J. Vanneste (1994): "Explaining Differences in Productive Efficiency: An Application to Belgian Municipalities," Public Choice, 80, 339-358.

Deller, S. (1992): "Production Efficiency in Local Government: A Parametric Approach," Public Finance, 47, 32-44.

Deller, S., D. Chicoine, And N. Walzer (1988): "Economies of Size and Scope in Rural Low-Volume Roads," Review of Economics and Statistics, 70, 459-465.

Deller, S. And J. Halstead (1994): "Efficiency in the Production of Rural Services: The Case of New England Towns," Land Economics, 70, 247-259.

Deller, S. AND C. Nelson (1991): "Measuring the Economic Efficiency of Producing Rural Road Services," American Journal of Agricultural Economics, 72, 194-201.

Deller, S., C. Nelson, And N. Walzer (1992): "Measuring Managerial Efficiency in Rural Government," Public Productivity and Management Review, 15, 355-370.

Doll, C., M. Helms, G. Liedtke, S. Rommerskirchen, W. Rothengatter, And M. VÖDIsch (2002): "Wegekostenrechnung für das Bundesfernstraßennetz," Tech. rep., Bundesministerium für Verkehr-, Bau- und Wohnungswesen.

FARrell, M. (1957): "The Measurement of Productive Efficiency," Journal of the Royal Statistical Society, Series A: General, 120, 253-281. 
Fried, H., C. Lovell, And S. Schmidt (2008): "Efficiency and Productivity," in The Mesurement of Productive Efficiency and Productivity Growth, ed. by H. Fried, C. Lovell, and S. Schmidt, Oxford: Oxford University Press, 3-92.

Geys, B. (2006): "Looking Across Borders: A Test of Spatial Policy Interdependence Using Local Government Efficiency Ratings," Journal of Urban Economics, 60, 443-446.

Geys, B., F. Heinemann, And A. Kalb (2008): "Voter Involvement, Fiscal Autonomy and Public Sector Efficiency: Evidence from German Municipalities," ZEW Discussion Paper No. 08-024.

Geys, B. And W. Moesen (2009): "Exploring Sources of Local Government Technical Inefficiency: Evidence from Flemish Municipalities," Public Finance and Management, 9, $1-29$.

Gimenez, V. AND D. Prior (2007): "Long- and Short-Term Cost Efficiency Frontier Evaluation: Evidence from Spanish Local Governments," Fiscal Studies, 28, 121-139.

Grossman, P., P. Mavros, and R. Wassmer (1999): "Public Sector Technical Inefficiency in Large U.S. Cities," Journal of Urban Economics, 46, 278-299.

Hines, J. And R. Thaler (1995): "Anomalies: The Flypaper Effect," Journal of Economic Perspectives, 9, 217-226.

HJalmarsson, L. And J. Odeck (1996): "Efficiency of Trucks in Road Construction and Maintenance: An Evaluation with Data Envelopment Analysis," Computers and Operations Research, 23, 393-404.

KALB, A. (2008): "The Impact of Intergovernmental Grants on Cost Efficiency: Theory and Evidence from German Municipalities," ZEW Discussion Paper No. 08-051.

Knack, S. (2002): "Social Capital and the Quality of Government: Evidence from the States," American Journal of Political Science, 9, 249-286.

Kumbhakar, S., S. Gosh, And J. McGuckin (1991): "A Generalized Production Frontier Approach for Estimating Determinants of Inefficiency in U.S. Dairy Firms," Journal of Business and Economic Statistics, 9, 279-286.

Kumbhakar, S. And C. Lovell (2000): Stochastic Frontier Analysis, Cambridge: Cambridge University Press.

Loikkanen, H. and I. Susiluoto (2005): "Cost Efficiency of Finnish Municipalities in Basic Service Provision 1994-2002," Urban Public Economics Review, 4, 39-63. 
Meeusen, W. And J. Van Den Broeck (1977): "Efficiency Estimation from CobbDouglas Production Functions with Composed Error," International Economic Review, $18,435-444$.

Mueller, D. (2003): Public Choice III, Cambridge: Cambridge University Press.

Neser, K. H. (2004): "Die Landkreise," in Taschenbuch Baden-Württemberg: Gesetze, Daten, Analysen, ed. by Landeszentrale für politische Bildung Baden-Württemberg and Statistisches Landesamt Baden-Württemberg, Stuttgart: Verlag W. Kohlhammer, 61-106.

Pitt, M. And M.-F. LeE (1981): "The Measurement and Sources of Technical Efficiency in the Indonesian Weaving Industry," Journal of Development Economics, 9, 43-64.

Rouse, P., M. Putterill, And D. Ryan (1997): "Towards a General Managerial Framework for Performance Measurement: A Comprehensive Highway Maintenance Application," Journal of Productivity Analysis, 8, 127-149.

Sampaio De Sousa, M. And B. Stosic (2005): "Technical Efficiency of the Barzilian Municipalities: Correcting Nonparametric Frontier Measurements for Outliers," Journal of Productivity Analysis, 24, 157-181.

Silkman, R. And D. Young (1982): "X-Efficiency and State Formula Grants," National Tax Journal, 35, 383-397.

Simar, L. AND P. Wilson (2007): "Estimation and Inference in Two-Stage, SemiParametric Models of Production Processes," Journal of Econometrics, 136, 31-64.

Sung, N. (2007): "Information Technology, Efficiency and Productivity: Evidence from Korean Local Governments," Applied Economics, 39, 1691-1703.

Vanden Eeckaut, P., H. Tulkens, and M. Jamar (1993): "Cost Efficiency in Belgian Municipalities," in The Measurement of Productive Efficiency: Techniques and Applications, ed. by H. Fried, C. Lovell, and S. Schmidt, New York: Oxford University Press, Inc.

Vitaliano, D. (1997): "X-Inefficiency in the Public Sector: The Case of Libraries," Public Finance Review, 25, 629-643.

Worthington, A. (2000): "Cost Efficiency in Australian Local Government: A Comparative Analysis of Mathematical Programming and Econometric Approaches," Financial Accountability and Management, 16, 201-224. 
Worthington, A. And B. Dollery (2000): "An Empirical Survey of Frontier Efficiency Measurement Techniques in Local Government," Local Government Studies, 26, 23-52. 


\section{Appendix A: Data Sources and Definitions}

The dataset used in all estimation approaches consists of 35 rural and 9 urban counties of the German state Baden-Württemberg for the period 1990 to 2004. All variables except of the variables "area of county roads", "maximum geographical point of county", and "rurality" come from the Statistical Office of Baden-Württemberg (Statistisches Landesamt Baden-Württemberg). The area of the county roads is obtained from the State Office for Street Engineering (Landesstelle für Straßentechnik Baden-Württemberg), the maximum geographical points of the counties by the State Surveying Office of Baden-Württemberg (Landesvermessungsamt Baden-Württemberg), and the index of rurality by the Federal Office for Building and Regional Planning (Bundesamt für Bauwesen und Raumordnung).

Total expenditures, county roads: These include all expenditures spent on county roads by the counties. According to the street law (Straßengesetz Baden-Württemberg), however, in municipalities with more than 30.000 inhabitants the cross-town links that are classified as county roads have to be financed by the municipalities and not by the counties (art. 43, para. 3). Moreover, all other municipalities have to finance the pavements and the parking spaces of cross-town links which are classified as county roads (art. 43, para. 4). Finally, county roads can sometimes be financed by third parties (e.g. administration unions), too (art. 45, para. 2). We deal with this problem by adding all the money spent on county roads by municipalities and third parties to the expenditures of the respective county. Formally, total expenditures (exp) for county roads (cr) are then given by (dropping time subscripts and subscripts for the counties):

$$
\exp ^{\text {total, } c r}=\exp ^{\text {counties, }, c r}+\exp ^{\text {municipalities, }, r}+\exp ^{\text {third parties, },} \text {. }
$$

Area of county roads: The area of the county roads is calculated by multiplying the length and the (average) width of the county roads (separated into cross-town links and roads outside of built-up areas), whereas the width includes the traffic lanes and hard shoulders. Cycle tracks and pavements are not contained in the width. Unfortunately, only the width of the county roads in 1996 was available. Therefore we used the width of 1996 to approximate the width of the roads for the other years. ${ }^{23}$ Formally, the area of the county roads is then calculated as follows:

$$
\operatorname{area}_{i, t}^{\text {county roads }}=\text { total length }{ }_{i, t}^{\text {county roads }} * \operatorname{width}_{i, 1996}^{\text {county roads }}
$$

\footnotetext{
${ }^{23}$ Since the width of the county roads changed only marginally in recent years, this is a minor problem.
} 
where $i$ is the subscript for the counties and $t$ is the time subscript.

Average (weighted) kilometres travelled on county roads per year: This indicator is composed of the kilometres travelled on county roads by (1) motorcycles, (2) cars, (3) trucks with a maximum total weight of (i) below 12 tons, and (ii) above 12 tons. Since the roads' rate of wear varies (substantially) between the four types of vehicles, every of the above mentioned categories is weighted differently. More specifically, we weighted the kilometres travelled of the four types of vehicles by the cost per kilometre caused by the respective type of vehicle (Wegekosten) calculated by Doll et al. (2002). ${ }^{24}$ Then, the average weighted kilometres travelled on county roads (AWKT) are calculated as follows (dropping time subscripts and subscripts for the counties):

$$
\mathrm{AWKT}=\frac{\mathrm{AWKT}^{m c}+2 * \mathrm{AWKT}^{c a r}+2.5 * \mathrm{AWKT}^{\text {trucks }<12 t}+15 * \mathrm{AWKT}^{\text {trucks }>12 t}}{\sum_{j=1}^{4} w_{j}},
$$

where $w$ represents the weights of the four types of vehicles.

Index of rurality: The three different types of counties are defined as follows:

Type 1: Agglomeration areas

1 Urban counties with more than 100.000 inhabitants

2 Counties with at least 300 inhabitants per square kilometre

3 Counties with at least 150 inhabitants per square kilometre

4 Counties with less than 150 inhabitants per square kilometre

\section{Type 2: Urbanised areas}

5 Urban counties with more then 100.000 inhabitants

6 Counties with at least 150 inhabitants per square kilometre

7 Counties with less than 150 inhabitants per square kilometre

\section{Type 3: Rural areas}

8 Counties with at least 100 inhabitants per square kilometre

9 Counties with less than 100 inhabitants per square kilometre

Note that type I areas are defined as regions with more than 300.000 inhabitants or with 300 inhabitants per square kilometre. In contrast, type II areas are regions with more than 150 inhabitants per square kilometre or with at least 100.000 inhabitants and 100 inhabi-

\footnotetext{
${ }^{24}$ Doll et al. (2002) calculate costs of $0.02 € /$ kilometre for motorcycles, of $0.04 € /$ kilometre for cars, of $0.05 € /$ kilometre $(0.30 € /$ kilometre $)$ for trucks with a maximum total weight of below (above) 12 tons for federal highways in Germany (in 2003).
} 
tants per square kilometre. The remaining regions are type III areas. The main difference between type III and type II areas is that the latter have a higher degree of urbanisation and a rudimental metropolitan centre.

Herfindahl index: The Herfindahl index (HI) is calculated by multiplying the squared seat shares (s) of the main national parties (from right to left: CDU, FDP, SPD, GRUENE) and of the "free voters unions" (fvu) in the county council:

$$
\mathrm{HI}=\mathrm{s}_{C D U}^{2}+\mathrm{s}_{S P D}^{2}+\mathrm{s}_{F D P}^{2}+\mathrm{s}_{G R U E N E}^{2}+\mathrm{s}_{f v u}^{2} .
$$




\section{Appendix B}

Table B1: Results of the first stage frontier estimation

\begin{tabular}{lc}
\hline \hline Variable & \\
\hline Constant & $\left(8.1160^{* *}\right.$ \\
& $(8.2819)$ \\
A: Area of county roads, log & $1.7123^{* *}$ \\
& $(5.3731)$ \\
B: Number of accidents due to & -0.0170 \\
bad road conditions, log & $(-0.0589)$ \\
$\mathrm{A}^{2}$ & -0.0224 \\
& $(-0.6629)$ \\
$\mathrm{B}^{2}$ & $0.0732^{* *}$ \\
& $(1.9690)$ \\
$\mathrm{A}^{*} \mathrm{~B}$ & $-0.1213^{* *}$ \\
& $(-2.9633)$ \\
\hline Log-likelihood & -234.89 \\
\hline \hline
\end{tabular}

Note: $\mathrm{N}=660$. Dependent variable: total expenditures for county roads. t-values are given in parentheses. ${ }^{* *}(*)$ denotes significance at $5 \%(10 \%)$ level. 